\title{
Enhanced weathering and carbonation of kimberlite residues from South African mines
}

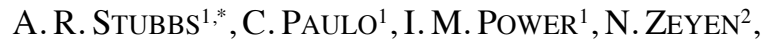 \\ AND S. A. WILSON ${ }^{2}$ \\ ${ }^{1}$ Trent School of the Environment, Trent University, \\ Peterborough, Canada (*amandastubbs@trentu.ca) \\ ${ }^{2}$ Department of Earth and Atmospheric Sciences, University \\ of Alberta, Edmonton, Canada
}

Volcaniclastic kimberlite residues from diamond mines undergo rapid weathering, thereby sequestering atmospheric carbon dioxide $\left(\mathrm{CO}_{2}\right)$ [1-2]. Residues from the Venetia Diamond Mine in South Africa are a valuable feedstock with the potential to sequester four to seven times their carbon emissions. These mine wastes are fine-grained $(<1 \mathrm{~mm})$, have high surface areas $\left(6.8-13.4 \mathrm{~m}^{2} / \mathrm{g}\right)$, and contain reactive mafic minerals including serpentine, diopside and clinochlore. Experiments utilized $\mathrm{CO}_{2}$ flux chambers to directly measure the removal of atmospheric $\mathrm{CO}_{2}$ within residues and mineral specimens. Residues dominated by massive volcaniclastic kimberlite gave a range of fluxes from -0.2 to $0 \mu \mathrm{mol} / \mathrm{m}^{2} / \mathrm{s}$ between 15-20\% volumetric water content (VWC). Fresh pulverized dark volcaniclastic kimberlite exhibited a greater negative flux when VWC reached $15-18 \%$ at a rate of between -0.6 to $-0.2 \mu \mathrm{mol} / \mathrm{m}^{2} / \mathrm{s}$. Sediments composed of either $10 \mathrm{wt} . \%$ brucite $\left[\mathrm{Mg}(\mathrm{OH})_{2}\right]$ mixed with quartz sand or 100 wt.\% forsterite $\left[\mathrm{Mg}_{2} \mathrm{SiO}_{4}\right]$ were tested to compare a highly reactive hydroxide with a less reactive silicate. These sediments had maximum negative fluxes of -1.9 and -0.5 $\mu \mathrm{mol} / \mathrm{m}^{2} / \mathrm{s}$, respectively. Our experiments demonstrate that the mineralogical composition, surface area exposure, and water content of residues affect the $\mathrm{CO}_{2}$ removal rate. Longterm weathering of kimberlite residues was explored using automated wet-dry cycles (4/day) over one year. Increases in the $\delta^{13} \mathrm{C}(+2.4 \%)$ and $\delta^{18} \mathrm{O}(+2.2 \%)$ values of carbonate minerals and increases in inorganic carbon indicate the storage of atmospheric $\mathrm{CO}_{2}$. Unweathered and weathered kimberlite samples collected at Voorspoed Diamond Mine in South Africa was explored to further understand long-term weathering of volcaniclastic kimberlites via changes in mineralogical composition, inorganic carbon content, and stable carbon isotopic compositions. This research is contributing towards the utilization of kimberlite residues for sequestration of atmospheric $\mathrm{CO}_{2}$ via enhanced weathering, a low cost and energy efficient strategy that makes use of waste pulverized rock.

[1] Mervine et al. (2018) Miner. Petrol. 112 (Suppl 2), S755S765. [2] Wilson et al. (2011) Environ. Sci. Technol.45, 7727-7736. 